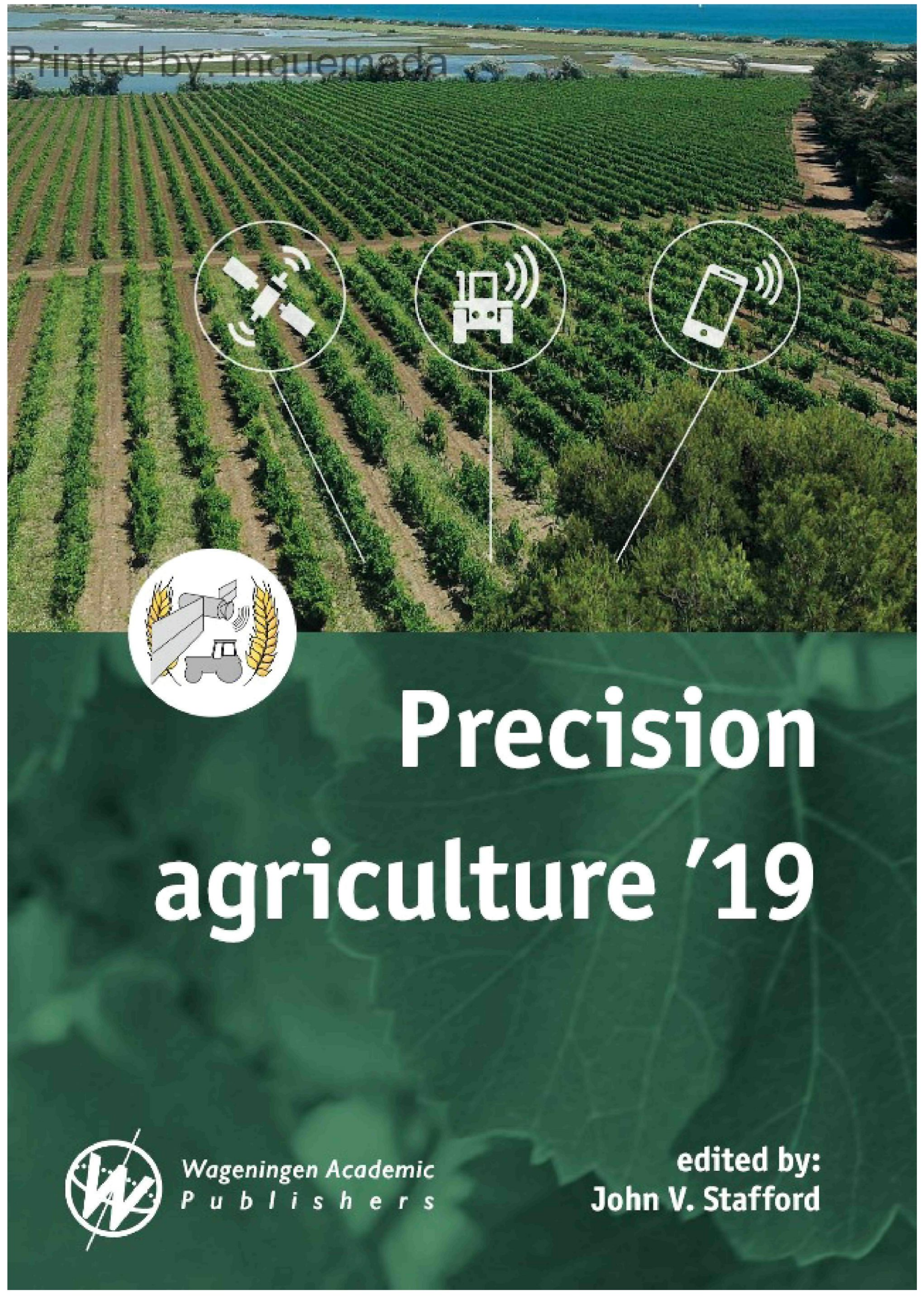




\title{
Vegetation indices from remote sensing imagery as proxies for yield and grain $\mathrm{N}$ in wheat
}

\author{
M. Quemada ${ }^{2}$, J.L. Pancorbo ${ }^{1}$, M. Alonso-Ayuso ${ }^{1}$, J.L. Gabriel ${ }^{2}$, J. López-Herrera ${ }^{1}$ and E. Pérez- \\ Martin $^{1}$ \\ ${ }^{I}$ Universidad Politécnica de Madrid. Avda. Complutense sn 28040 Madrid, Spain; \\ miguel.quemada@upm.es \\ ${ }^{2}$ INLA-INAGEA. Ctra. de la Coruña km 7,5, 28040 Madrid, Spain
}

\begin{abstract}
The use of vegetation indices (VIs) might help to adjust fertilizer and irrigation, increase yield and reduce costs and nitrogen $(\mathrm{N})$ losses. The objectives were to evaluate the use of VIs extracted from remote sensing imagery to estimate crop $\mathrm{N}$ status, yield and grain $\mathrm{N}$ content in wheat (Triticum aestivum, L.). A field experiment conducted with four $\mathrm{N}$ fertilizer levels randomly distributed in 32 plots ( $\left.25 \times 25 \mathrm{~m}^{2}\right)$, half irrigated and half rain-fed. At two sampling times, biomass and $\mathrm{N}$ uptake were determined, ground sensors measurements were taken, and multi-spectral imagery was acquired by an unmanned aerial vehicle. At harvest, yield was recorded with a combine and grain $\mathrm{N}$ determined. VIs obtained from ground measurements were highly correlated with those from the aerial platform. Using planar domain VIs, which relate $\mathrm{N}$ concentration and biomass, correlated well to crop $\mathbf{N}$ status and showed high potential for fertilizer recommendation, as well as yield and grain $\mathrm{N}$ prediction in wheat.
\end{abstract}

Keywords: nitrogen fertilization, crop sensors, unmanned aerial vehicle

\section{Introduction}

According to FAO, $15.9 \%$ of the total primary crops area harvested in the world was wheat (Triticum aestivum, L) in 2016. Adjusting fertilization to wheat requirements is a crucial strategy for increasing $\mathrm{N}$ use efficiency and reducing water and soil pollution (Arregui et al., 2006). In recent years, different techniques have been applied and tested by researchers and farmers to determine the crop $\mathrm{N}$ status. Laboratory plant tissue analysis is a reliable method for calculating crop $\mathrm{N}$ status but it is expensive, slow and hard to apply to large fields (Haboudane et al, 2002). In addition, in many cases, by the time the results are available, the physiological state of the crop has changed and it is of little support for decision making. The use of handheld chlorophyll meters (CM) has increased in recent years because it is a non-destructive and rapid method for measuring leaf chlorophyll and detecting $\mathrm{N}$ deficiencies (Tremblay et al., 2009). Nevertheless, using CM to acoount for spatial variability in large fields could be very time-consuming. These limitations could be overcome by remote sensing, and its application to fertilizer management is providing valuable insights into improving decision making. Airborne sensors are used to measure canopy reflectance at different wavelengths, and the actual spectrum is affected by both vegetation structure and crop $\mathrm{N}$ concentration (Gabriel $e t$ al. 2017). Based on this, many vegetation indices (VIs) have been developed to estimate crop $\mathrm{N}$ status (Chen et al., 2010, Fitzgerald et al., 2010). However, each crop requires a specific strategy for adjusting $\mathrm{N}$ fertilizer application depending on temporal evolution of crop $\mathrm{N}$ demand and quality criteria. Monitoring temporal variations in crop $\mathrm{N}$ content could allow adapting $\mathrm{N}$ application to crop $\mathrm{N}$ requirements over large areas of specific crops (Quemada et al., 2014). In winter wheat, a common strategy is to split the synthetic fertilizer into two topdressings applications: one at the beginning of tillering and the rest during stem elongation for ensuring yield (Arregui et al., 2006). Thereafter, foliar applications around flowering may be applied to increase grain protein content. 
The objectives of this study were to evaluate remotely sensed data to estimate biomass and crop $\mathrm{N}$ status at early stages and to predict yield and grain $\mathrm{N}$ concentration at harvest. Additionally, the use of planar domain VIs, that combine chlorophyll and structural VIs, was tested to see if they improved the estimation and prediction of crop variables.

\section{Materials and methods}

The study was carried out at La Chimenea field station, Central Spain $\left(40^{\circ} 04^{\circ} \mathrm{N}, 03^{\circ} 32^{\prime} \mathrm{W}, 550 \mathrm{~m}\right.$ a.s.l.) in a quarter of a $220 \mathrm{~m}$ radius pivot. The soil was mapped as Haplic Calcisol, had a $\mathrm{pH} \approx 8.1$, medium organic matter content, and a silty clay loam texture with low stone content throughout the soil profile. The study site was flat and the slope was $<1 \%$. The climate was classified as cold semi-arid (Bsk) according to Köppen classification. Normally, spring and summer are characterized by a large water deficit, but the spring 2018 was unusually wet. In the pivot, uniformly sown with winter wheat on November 2, 2017, were marked 32 plots ( $25 \times 25 \mathrm{~m})$.

A factorial experiment was established by randomly distributing the plots into four $\mathrm{N}(0,50,100$ and $150 \mathrm{~kg} \mathrm{~N} / \mathrm{ha}$; NO, N1, N2 and N3, respectively) and two water levels, with four replications (Figure 1). Nitrogen fertilizer was hand broadcasted to plots in two stages: two thirds on January 25 (GS22) and one third on March 25 (GS35). Growth stages (GS) followed the decimal code (Lancashire et al. 1991). Half of the plots received irrigation on May 8 to match crop water evapotranspiration with availability, whereas the other half remained rain-fed. All plots were harvested on July 20 . Plots were georeferenced with RTK (Real Time Kinematic) through Global Navigation Satellite System (GNSS) technique with a HiPer Pro receptor (Topcon Singapore Holdings Pte. Ltd, Singapore). The previous year, the field was sown with maize to ensure uniformity and low levels of soil inorganic N. Before sowing wheat, $50 \mathrm{~kg} P / h a$ and $70 \mathrm{~kg} \mathrm{~K} / \mathrm{ha}$ were applied.

\section{Crop analysis}

Crop data were obtained at two different stages: at the mid-stem elongation (GS34, March 22) and at flowering (GS65, May 11). At each date, two biomass samples $(0.50 \times 0.50 \mathrm{~m})$ were collected in each plot, dried at $65^{\circ} \mathrm{C}$ and weighed to determine aerial biomass. A subsample was analysed for determining $\mathrm{N}$ concentration ( $\% \mathrm{~N}$ ) by the Dumas combustion method (LECO FP-428 analyser, St. Joseph, MI, USA). At harvest, the central stripe $(1.5 \times 20 \mathrm{~m})$ of each plot was harvested with an experimental combine to measure yield, and a grain subsample of each plot was saved for analyzing grain $\mathrm{N}$ concentration by the Dumas method. For each plot, $\mathrm{N}$ content was calculated by multiplying $\mathrm{N}$ concentration times the aerial biomass. At harvest, the grain $\mathrm{N}$ content was calculated by

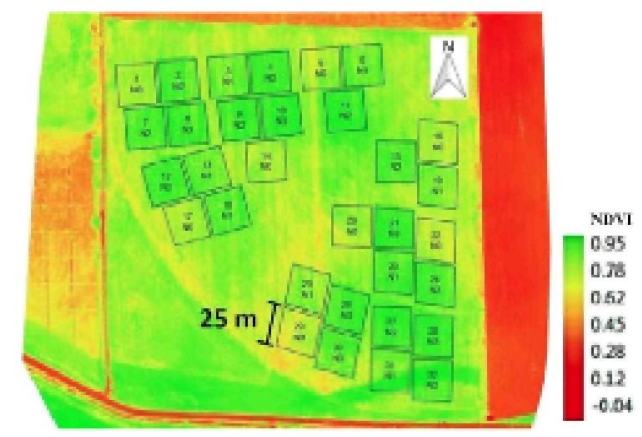

Figure 1. Normalized difference vegetation index (NDVI) from a field multi-spectral image with plot number and fertilizer level. 
multiplying the grain $\mathrm{N}$ concentration times the yield. To measure the crop $\mathrm{N}$ status, the Nitrogen Nutrition Index (NNI) was calculated by referring the $\% \mathrm{~N}$ and biomass obtained at each sampling date (Mistele and Schmidhalter, 2008).

Ground-level optical measurements

Non-destructive measurements with two commercial optical sensors were taken to monitor the crop status at each sampling date. Dualex* Scientific (Force-A, Orsay, France), is a leaf clip sensor for testing crop $\mathrm{N}$ status and measures chlorophyll content (Chl) based on the ratio of the transmitted light at the red and infrared wavelengths (Tremblay ot al., 2009). This device also measures leaf flavonoid (FLAV) concentration by determining the optical absorption of the leaf epidermis under UV light. The Nitrogen Balance Index (NBI) is calculated as the ratio of Chl and FL.AV. Greenseeker* (Handhèld Crop Sensor Model HCS-100, Trimble, Sunnyvale, CA, USA) is an active light proximal sensor that measures NDVI. The sensor emits a burst of red and infrared light and measures the ratio of the light that is reflected. Each sampling date, the mean $\mathrm{Chl}_{\text {, }} \mathrm{NBI}_{\text {, }}$ and Greenseeker were obtained as the average of 15 measurements per plot.

Renote sensing data acquisition and VI extraction

During stem elongation and flowering, two airborne campaigns were conducted as close as possible to ground-level measurements, ensuring a cloud-free sky day. The UAV images were acquired with a multi-spectral sensor (RedEdge-M, MicaSense, Inc., Seattle, USA) with an Instrument Landing System sensor and GNSS, $80 \mathrm{~m}$ over the experimental plots, on the solar plane at 11:40 GMT. Before and after the flights, images of the reflectance calibration panel for the camera were taken. The flight was conducted optimizing the path of the UAV through parallel tracks, with automatic pilot function according to the project plan, with a ground sampling distance of $6.81 \mathrm{~cm}$. The UAV hexacopter used a system GPS A3 Pro of dual frequency, and a Ronin-MX stabilizer for the cameras with an inertial system for the positioning of the photo-centers. Seven control points were positioned on the ground with a GNSS in order to ensure an ortho-rectified image of the plots, providing a

Table 1. Vegetation indices used in this study.

\begin{tabular}{|c|c|c|}
\hline Index & Equation & Reference \\
\hline \multicolumn{3}{|c|}{ Structural indices } \\
\hline Normalized Difference Vegetation Index & $\begin{array}{l}\mathrm{NDVI}=(\mathrm{R} 800-\mathrm{R} 670) / \\
(\mathrm{R} 800+\mathrm{R} 670)\end{array}$ & Rouse et al., 1974 \\
\hline Reformed Difference Vegetation Index & $\begin{array}{l}\mathrm{RDV}=(\mathrm{R} 800-\mathrm{R} 670) / \\
\mathrm{R} 800+\mathrm{P} 670)^{2}\end{array}$ & Roujean et al., 1995 \\
\hline \multicolumn{3}{|l|}{ Chlorophyll indices } \\
\hline Normalized Difference Red Edge & $\begin{array}{l}\text { NDRE }=(\mathrm{R} 790-\mathrm{R} 720) / \\
(\mathrm{R} 790+\mathrm{R} 720)\end{array}$ & Fitzgerald et al.. 2010 \\
\hline $\begin{array}{l}\text { Transformed Chlorophyll Absorption in } \\
\text { Reflectance Index }\end{array}$ & $\begin{array}{l}\text { TCARI }=3[(\mathrm{R} 700-\mathrm{R} 670)- \\
0.2 \times(\mathrm{R} 700-\mathrm{R} 550) \times(\mathrm{R} 700 / \mathrm{R} 670)]\end{array}$ & Haboudane et al., 2002 \\
\hline $\begin{array}{l}\text { Optimized soil-adjusted vegetation } \\
\text { index }\end{array}$ & $\begin{array}{l}\text { OSAVI }=(1+0.16) \times(R 800-R 670) / \\
(R 900+R 670+0.16)\end{array}$ & Rondeaux et ol., 1996 \\
\hline Combined & TCARI/OSAVI & Haboudane et al. 2002 \\
\hline Double-Peak Canopy Nitrogen Index & $\begin{array}{l}\mathrm{DCNI}=[\mathrm{R} 720-\mathrm{R} 700) / \\
(\mathrm{R} 700-\mathrm{R} 670)] /(\mathrm{R} 720-\mathrm{R} 670+0.03)\end{array}$ & Chen et al., 2010 \\
\hline NG & NG $=$ NIR/Green & \\
\hline
\end{tabular}


5.4 cm/pixel tesolution. 'l his cinematic support was contrasted with the on-ground data, obtaining a precision of $29 \mathrm{~mm}$ in $X, 33 \mathrm{~mm}$ in $Y$ in planimetry and $21 \mathrm{~mm}$ in altimetry 2 .

'I he camera had five independent image certsors that captured narrow' wavelength bands centered at $475,560 \mathrm{~nm}$ with a bandwidtl of $20.0 \pm 2 \mathrm{nth}$, $66 \mathrm{~B}, 700 \mathrm{~nm}$ with a bandwidth of $10.0 \pm 2 \mathrm{~nm}$, and 800 nm with a bandwidth of $40.0 \pm 2$ nm. "The sensors prowided inages made up of $1,240 \times 960$ pirels. "Ihe orthö-image was used to ext aùt eight different VIs, classified as struchural or duorophyll indices, for each experimental plot using equations in Table $\mathbf{I}$.

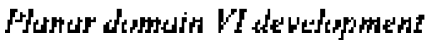

Plantar domain indices were developed by represent ing in $\mathrm{X}$ axis each structural index and in $\mathrm{X}$ axis each ch lorophyll index from 'Iable I (Hitzgerald et al. 2010). 'These indices measure the relationship between the two v's represented by comparing the distance of each point to the upper and bottom line that involve the cloud of points. well fertilized plots will have a high walue of both indicen so will be close to the upper line, whereas $N$ deficient plots will approach the bottom line 'the canopy chlorophyll content index (CCCI) is a plamar domain WI developed by Fitzgerald at al. (2010) designed to detect canopy $N$ using NDVI as structural, and NDFE as chlorophyll indices. 'the indices obtained in this shdy will be compared with COCI.

\section{Statisticul walynisi}

Multifatorial ANOWA analysis was conducted with the data obtained at barvest to determine the effect of $\mathrm{N}$ and water factös. A correlation analysis was performed to obtain the determination coefficient $\left(\mathrm{H}^{2}\right)$ berween wis and agronomic variables, and for messuremtents of different sensors. Statistical analyses were performed with $\mathbf{R}$ software [ $\mathbf{R}$ Core tean, 2018).

\section{Kesults.}

\section{Cropdota}

Yield was highly affected by $N$ treatments ( $p$ o.001), but not by the itrigation level (pon. 1 ), probably due to the wnusually wet spritg. 'Iherefore, the water factor was not taken into account whel studying the ctop yield response. A linear-linear plateau model fit the yield tesponse curve to N fertilizer

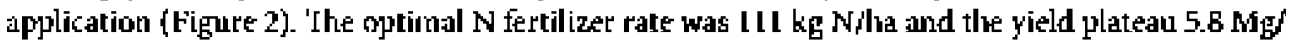

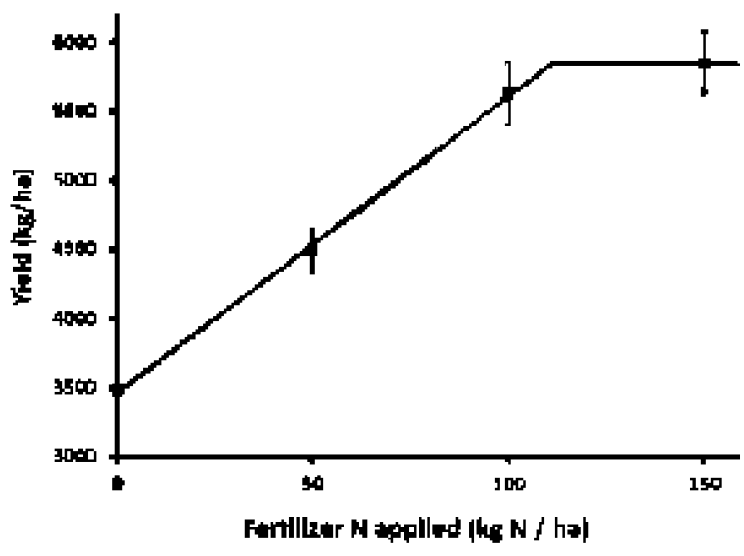

Figure 2 . Yield response curwe of wheat to N fertilizer rate. Squares are the mean with standard errors as bars, and the line is the adjusted linear-linear plateau model. 
ha. The mean NNI of the three sampling dates was 0.8 for N0 treatment, 0.9 for $\mathrm{N}_{1}, 1.1$ for $\mathrm{N} 2$, and 1.4 for $\mathrm{N} 3$, highlighting that $\mathrm{N} 0$ and $\mathrm{N} 1$ treatments were $\mathrm{N}$ limited whereas $\mathrm{N} 2$ and $\mathrm{N} 3$ were not. The statistical analysis showed that the $\mathrm{N}$ treatments affected in a significant way grain $\mathrm{N}$ and grain $\mathrm{N}$ content $(P<0.01)$. The irrigation levels affected significantly grain $\mathrm{N}(P<0.01)$ but not grain $\mathrm{N}$ content $(P>0.1)$. Results indicated that with a higher irrigation amount, the grain $\mathrm{N}$ concentration decreased (Figure 3)

\section{Crop $N$ status and biomass}

The relationship between ground level sensors and crop $\mathrm{N}$ status were better for the measurements taken at GS65 than at GS34 (Table 2). Determination coefficients were higher for $\mathrm{N}$ content, then for $\mathrm{N}$ concentration and NNI. Dualex measurements, both Chl and NBI, had an $\mathrm{R}^{2} \geq 0.6$ with N content at GS34 showing high potential for adjusting $\mathrm{N}$ fertilization in early stages. The relationship between Dualex and Chlorophyll indices from the multi-spectral image with crop biomass was significant and improved in GS65 compared to GS34.

The relationships between airborne structural indices (NDVI, RDVI) with biomass and crop N status improved when measurements were taken at GS65 (Table 2). The chlorophyll indices (TCARI, NDRE, DCNI, OSAVI, COMBINED, NG) were highly correlated to $\mathrm{N}$ content and biomass, but less to $\mathrm{N}$ concentration, especially at GS65. Among Chlorophyl indices, NG and OSAVI showed the best correlation with $\mathrm{N}$ concentration at both stages. The best correlation with most of the physiological variables was obtained with planar domain indices, particularly using NG as chlorophyll and NDVI as structural index (NG-NDVI). The main reason is that NG-NDVI did not saturate at high $\mathrm{N}$ fertilization rates.

The multi-spectral VIs that had the best relationship with Dualex $\mathrm{Chl}$ were DCNI $\mathrm{UAw}_{\mathrm{NDRE}} \mathrm{NAy}_{\mathrm{U}}$ and $\mathrm{NG}_{\mathrm{UAV}}$ Relationships between these airborne indices and Dualex Chl improved at a later GS. The relationship between NDVI measured with Greenseeker and extracted from the multi-spectral image was highly significant $\left(R^{2}>0.9\right)$.

\section{Crop yield}

Indices obtained from sensor measurements, either at ground level or from UAV, had a highly significant relationship with wheat yield at harvest at both growth stages (Table 3 ). In similar studies conducted in maize, relationships between optical sensors in early growth stages and crop $\mathrm{N}$ status or yield were much lower than in wheat (Quemada et al., 2014; Gabriel et al., 2017). This could be explained by differences in canopy structure between both crops, while wheat reached a
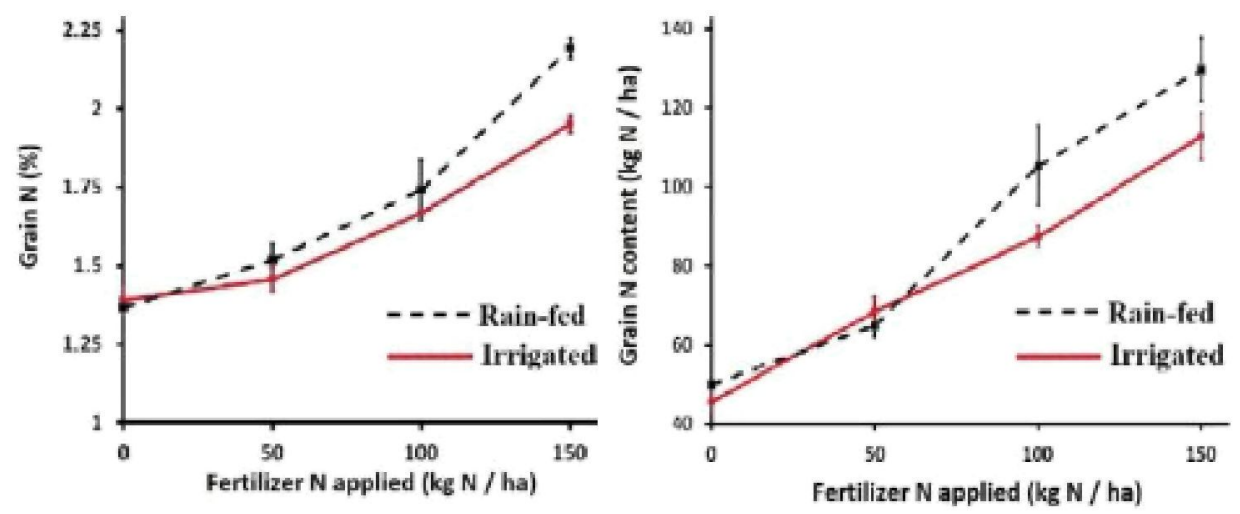

Figure 3. Grain $\mathrm{N}$ concentration ( $\%$ ) and grain $\mathrm{N}$ content $(\mathrm{kg} \mathrm{N} / \mathrm{h}$ ) at harvest for the various $\mathrm{N}$ levels and for the rain-fed and irrigated treatments. Squares are the mean with standard error as bars. 
Table 2. Determination coefficient $\left(R^{2}\right)$ between crop variables, ground level sensors (Dualex, Greenseeker) and indices extracted from the multi-spectral image acquired from a UAV at different growth stages (GS). Highly significant determination coefficients are marked in bold. [N] is biomass Nitrogen concentration.

\begin{tabular}{|c|c|c|c|c|c|c|c|c|}
\hline & \multicolumn{4}{|c|}{ Stem elongation (GS34) } & \multicolumn{4}{|c|}{ Flowering (GS65) } \\
\hline & Biomass & {$[\mathrm{N}]$} & $\begin{array}{l}\mathrm{N} \\
\text { conten }\end{array}$ & NNI & Biomass & {$[\mathrm{N}]$} & $\begin{array}{l}\mathrm{N} \\
\text { content }\end{array}$ & NNI \\
\hline Dualex Chl & 0.54 & 0.44 & 0.6 & 0.44 & 0.76 & 0.51 & 0.65 & 0.51 \\
\hline Dualex NBI & 0.48 & 0.51 & 0.61 & 0.51 & 0.79 & 0.54 & 0.7 & 0.54 \\
\hline Greenseker NDM1 & 0.51 & 0.29 & 0.48 & 0.29 & 0.61 & 0.56 & 0.62 & 0.56 \\
\hline $\mathrm{NDV}_{\text {UAV }}$ & 0.55 & 0.29 & 0.51 & 0.29 & 0.65 & 0.56 & 0.62 & 0.56 \\
\hline RDVl $_{\text {UAV }}$ & 0.45 & 0.37 & 0.49 & 0.37 & 0.6 & 0.25 & 0.37 & 0.25 \\
\hline TCARI $_{\text {UAV }}$ & 0.3 & 0.22 & 0.34 & 0.22 & 0.65 & 0.54 & 0.62 & 0.54 \\
\hline NDRE $_{\text {UAN }}$ & 0.04 & 0.05 & 0.05 & 0.05 & 0.78 & 0.6 & 0.71 & 0.59 \\
\hline $\mathrm{DCNI}_{\mathrm{UN}}$ & 0.17 & 0.07 & 0.14 & 0.07 & 0.71 & 0.35 & 0.52 & 0.35 \\
\hline OSAV| $_{\text {UAV }}$ & 0.51 & 0.35 & 0.52 & 0.35 & 0.71 & 0.61 & 0.69 & 0.61 \\
\hline COMBINEDI & 0.32 & 0.23 & 0.36 & 0.23 & 0.68 & 0.56 & 0.64 & 0.56 \\
\hline $\mathrm{NG}_{\text {UAV }}$ & 0.59 & 0.35 & 0.57 & 0.35 & 0.75 & 0.6 & 0.71 & 0.6 \\
\hline $\mathrm{NG}-\mathrm{NDV} \mathrm{l}_{\text {UAV }}$ & 0.6 & 0.35 & 0.58 & 0.35 & 0.76 & 0.59 & 0.71 & 0.59 \\
\hline $\mathrm{NG}-\mathrm{RDV} \mathrm{L}_{\mathrm{UAV}}$ & 0.62 & 0.31 & 0.56 & 0.31 & 0.73 & 0.54 & 0.66 & 0.54 \\
\hline $\mathrm{CCCl}_{\text {UN }}$ & 0.03 & 0 & 0.02 & 0 & 0.84 & 0.57 & 0.72 & 0.56 \\
\hline
\end{tabular}

near complete ground cover since early GS, maize only attains a high ground cover at advanced GS. These results highlight the potential of optical sensors for adjusting $\mathrm{N}$ fertilization to wheat demand.

\section{Grain protein content}

Dualex indices provided better estimation of grain $\mathrm{N}$ concentration and grain $\mathrm{N}$ content than the proximal sensor Greenseeker (Table 3). This is in agreement with results from the literature that showed the potential of leaf clip chlorophyll meters for estimating grain protein in wheat (Arregui st al. 2006).

In a similar way, structural indices obtained from airborne imagery had a lower relationship with grain $\mathbb{N}$ and grain $\mathbb{N}$ content than planar domain indices. Particularly, the NG-NDVI planar domain index had an $\mathrm{R}^{2}>0.60$ in GS37 and GS65 (Table 3), these are dates in which decision making for foliar $\mathrm{N}$ application to increase grain protein are usually taken by farmers.

\section{Conclusions}

These results highlight that a relevant application of remote sensing is the prediction of wheat yield and grain protein. Multi-spectral imagery was a useful tool for $\mathrm{N}$ fertilizer adjustment and, therefore, it could be used to redwce costs and increase the $\mathrm{N}$ use efficiency. Planar domain indices proposed in this study showed a better predictive capacity for wheat crop at stem elongation and flowering than other VIs, like NDVI. Combining structural and chlorophyll indices in planar domain indices improved the relationship with biomass and N content at both growth stages, GS34 and GS65. 
Table 3. Determination coefficient $\left(\mathrm{R}^{2}\right)^{2}$ between estimations developed at different $G S$ with yield, grain N concentration and grain N content at harvest. Highly significant determination coefficients are marked in bold.

\begin{tabular}{|c|c|c|c|c|c|c|}
\hline & \multicolumn{3}{|c|}{ Stemelongation (GS34) } & \multicolumn{3}{|c|}{ Flawellng (G565) } \\
\hline & Meld & Grain N & Graln N content & Yleld & Graln $N$ & Graln N content \\
\hline Dualex Chl & 0.7 & 0.63 & $0 . \pi$ & 0.59 & 0.64 & 0.74 \\
\hline Dualex Na & 0.68 & 0.51 & 0.71 & 0.7 & 0.69 & 0.76 \\
\hline Greenseker NDWI & 0.72 & 0.55 & D. 7 & 0.57 & 0.56 & to.66 \\
\hline$N\left[\left.W\right|_{\text {UAS }}\right.$ & 0.7 & 0.48 & 0.63 & 0.7 & 0.52 & 0.66 \\
\hline RDVI & 0.7 & 0.54 & D.6. & 0.47 & 0.24 & 0.35 \\
\hline TCAFU & 0.39 & 0.28 & 0.37 & 0.67 & 0.49 & 0.63 \\
\hline NDFEE & 0.06 & 0.17 & 0.11 & 0.75 & 0.6 & 0.74 \\
\hline DGN| & 0.23 & 0.04 & 0.13 & 0.43 & 0.55 & 0.55 \\
\hline OSAYVI & 0.72 & 0.53 & 0.67 & 0.74 & 0.59 & 0.72 \\
\hline COMEINEDI & 0.42 & 0.25 & 0.39 & 0.71 & 0.51 & 0.66 \\
\hline 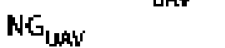 & 0.74 & 0.61 & 0.74 & 0.74 & 0.62 & 0.75 \\
\hline 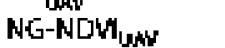 & 0.74 & 0.62 & 0.74 & 0.73 & 0.65 & 0.76 \\
\hline NG-RCDI INAY & 0.71 & 0.57 & 0.7 & 0.7 & 0.56 & 0.7 \\
\hline $\mathrm{CCCI}_{\amalg \text { 的 }}$ & 0.03 & 0 & 0 & 0.72 & 0.62 & 0.75 \\
\hline
\end{tabular}

Acknowledgements

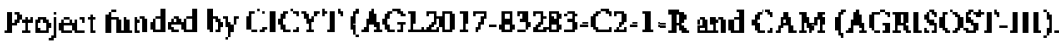

\section{Eeferences}

Arregui, LM- Lasa, Ek, Lafarga, A., Lrancta, 1., baroja, E. and Quemada, M., 2006. Evaluation of chlorephyn meter as tools for $\mathrm{N}$ fertilization in winter whest under humid Mctiterranean conditions. Eurnporan |aurnal of ayron-orny, 24, 140-14th.

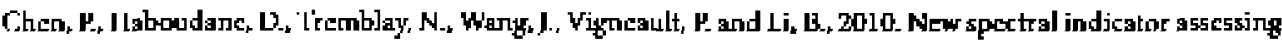

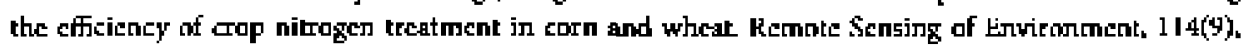
$1997-1997$

Hitrycrald, G.. Modrigucx, D. and O'Leary, G., 2010. Measuring and predicting canopy ritrogen nutrition

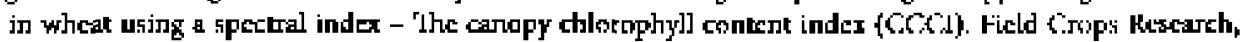
$110(3), 318-3.24$.

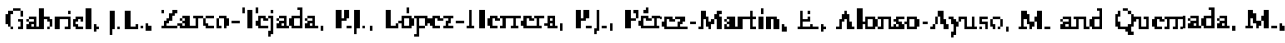

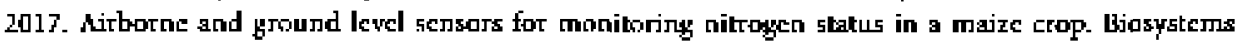
Enginecring, 1600, 124-133

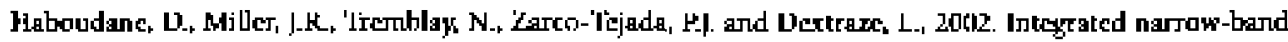

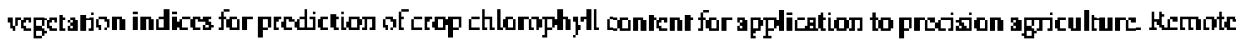
:icrsing of Emwironment, $81,416-426$.

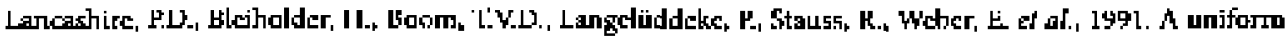

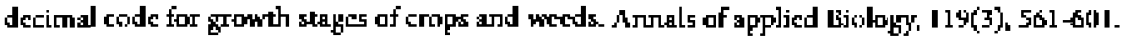

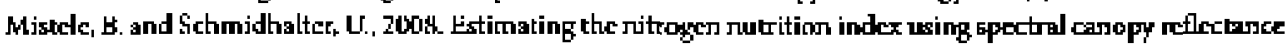

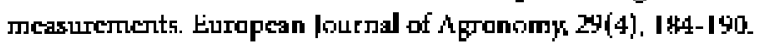


Quemada, M-- Gabriel, J.L. and Zarco-Tejada, P., 2014. Airborne hyperspectral images and ground-lewel optical sensors as assessment tools for maize nitrogen fertilization. Remote Sensing, 6, 2940-2962.

R Core Team, 2018. R. A Language and Environment for Statistical Computing. R Foundation for Statiatical Computing, Vienna, Austria.

Rondeaux, G., Steven, M. and Baret, F., 1996. Optimization of soil-adjusted vegetation indices. Remote Sensing of Environment, 55, 95-107.

Roujean, J.L. and Breon, F.M., 1995. Estimating PAR absorbed by vegetation from bidirectional reflectance measurements. Remote Sensing of Environment, 51, 375-384.

Rouse, J.W., Haas, R.H., Schell, J.A., Deering, D.W. and Harlan, J.C., 1974. Monitoring the vernal advancement of retrogradation of natural vegetation, NASA/GSF, Type III, Final Report. Greenbelt, MD, USA, 371.

Tremblay, N., Wang, Z. and Belec, C., 2009. Performance of Dualex in spring wheat for crop nitrogen status assessment, yield prediction and estimation of soil nitrate content. Journal of Plant Nutrition, 33(1), 57-70. 